\title{
"Determinants of interest margins in Spanish credit institutions before and after the 2008 financial crash"
}

\begin{tabular}{|c|c|}
\hline AUTHORS & $\begin{array}{l}\text { Salvador Climent Serrano } \\
\text { Jose M. Pavía } \\
\text { Fernando Toboso }\end{array}$ \\
\hline ARTICLE INFO & $\begin{array}{l}\text { Salvador Climent Serrano, Jose M. Pavía and Fernando Toboso (2017). } \\
\text { Determinants of interest margins in Spanish credit institutions before and after the } \\
2008 \text { financial crash. Banks and Bank Systems, 12(2), 39-50. } \\
\text { doi:10.21511/bbs.12(2).2017.04 }\end{array}$ \\
\hline DOI & http://dx.doi.org/10.21511/bbs.12(2).2017.04 \\
\hline RELEASED ON & Friday, 23 June 2017 \\
\hline RECEIVED ON & Sunday, 05 February 2017 \\
\hline \multirow[t]{2}{*}{ ACCEPTED ON } & Tuesday, 25 April 2017 \\
\hline & $(\mathrm{cc}) \mathbf{E Y}$ \\
\hline LICENSE & $\begin{array}{l}\text { This work is licensed under a Creative Commons Attribution } 4.0 \text { International } \\
\text { License }\end{array}$ \\
\hline JOURNAL & "Banks and Bank Systems" \\
\hline ISSN PRINT & $1816-7403$ \\
\hline ISSN ONLINE & $1991-7074$ \\
\hline PUBLISHER & LLC "Consulting Publishing Company "Business Perspectives" \\
\hline FOUNDER & LLC "Consulting Publishing Company "Business Perspectives" \\
\hline
\end{tabular}

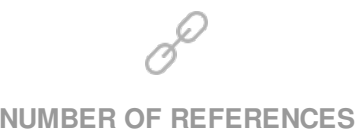

24

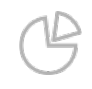

NUMBER OF FIGURES

1

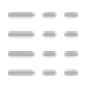

NUMBER OF TABLES

3

(C) The author(s) 2023. This publication is an open access article. 
Salvador Climent Serrano (Spain), Jose M. Pavía (Spain), Fernando Toboso (Spain)

\title{
Determinants of interest margins in Spanish credit institutions before and after the 2008 financial crash
}

\begin{abstract}
As interest margins of credit institutions affect economic performance of countries, finding out which are the main determinants of their evolution is a research task of great interest at current times. This is the purpose of the present paper as regards to the Spanish case over the period 2004-2012. Based on the econometric contributions by Ho and Saunders (1981) and some of its extensions, the authors develop a model that includes as explanatory variables the factors usually examined in the literature and other singular variables that might be relevant. Particularly, the rate of leverage, the quality of their assets measured according to their risk, and the profit obtained from the selling of assets, including real estate ones. The research also provides an analysis of differences between banks and savings banks.
\end{abstract}

Keywords: rate of leverage, quality of assets, banks and savings banks, 2008 financial crash.

JEL Classification: G21, G28, G34.

Received on: $5^{\text {th }}$ of February, 2017.

Accepted on: $25^{\text {th }}$ of April, 2017.

\section{Introduction}

Among the traditional functions of credit institutions, a key one is that of capturing funds from savers to offer them to those in need of funding. Obviously, in a market economy, the interests paid to savers are usually lower than those charged to debtors. This provides credit entities with positive interest margins that help them in their permanent attempt to cover costs, including capital costs arising from depreciation, and also pay dividends.

The purpose of the present paper consists in investigating how did interest margins of banks in fact evolved in Spain over the period 2004-2012, for, then, estimating with econometric techniques, which may have been the main determinants of the abovementioned evolution.

Figure 1 shows the said evolution of the average interest rate charged and paid by the Spanish credit institutions over the 2004-2012 period investigated, as well as the average interest margin. As showed, the average margin appears quite stable over more than half of the years considered (1.51\% in 2004 to $1.58 \%$ in 2007$)$, then, grows over the period 2008-2010 $(1.68 \%$ in 2008 to $2.63 \%$ in 2010 ), to finally start reducing slowly in $2011(2.62 \%)$ and substantially in 2012 (1.90\%).

(C) Salvador Climent Serrano, Jose M. Pavía, Fernando Toboso, 2017. Salvador Climent Serrano, Ph.D., Department of Financial and Actuarial Economics, University of Valencia, Spain.

Jose M. Pavía, Ph.D., Department of Applied Economics, University of Valencia, Spain.

Fernando Toboso, Ph.D., Department of Applied Economics, University of Valencia, Spain.

This is an Open Access article, distributed under the terms of the Creative Commons Attribution 4.0 International license, which permits unrestricted re-use, distribution, and reproduction in any medium, provided the original work is properly cited.
What are, then, the main factors explaining such an evolution? For answering this question, we have to start from the work of Ho and Saunders (1981). However, we will develop a model that includes as explanatory variables not only those factors usually examined in the literature, but also some other singular variables that have not received enough attention. Therefore, besides those traditional factors, we will also test as potential determinants three additional variables that might be relevant for the Spanish case: the rate of leverage, the quality of their assets measured according to their risk, and the profit they obtain from the sale of assets, including those real estate properties in which they invested over the boom. We also provide an analysis showing some differences between banks and savings banks. In addition, we will also test separately each of the four sources of income not linked with the interest margin, that is, we will differentiate between incomes obtained from capital investments, from commissions, from financial investments (purchase-sale of financial instruments) and from other income sources.

The research results provided by our study as regards to saving banks, in the Spanish case, as compared to banks, may be of some interest too for those countries in which saving banks still share a significant quota of the intermediation market, as is the case of Germany, for example.

The rest of the paper is organized as follows. Section 1 gives a brief review of key publications on these issues. In section 2, we explain the model and the variables to be tested, as well as the expected sign of the coefficient in each case. In section 3 we explain the results obtained. Finally, last section provides some concluding remarks. 

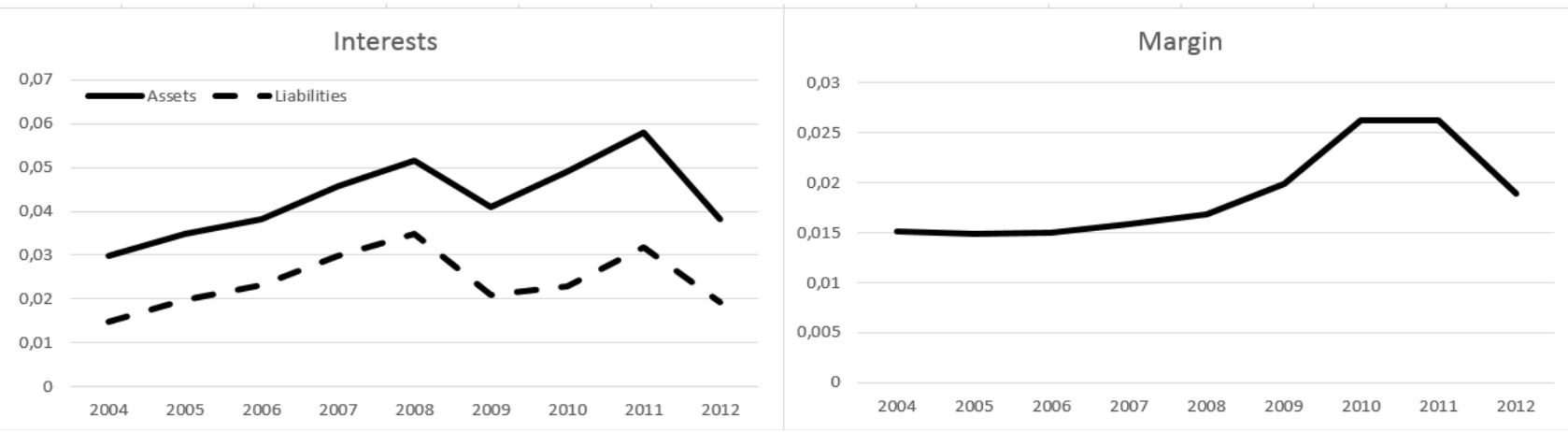

Fig. 1. Nominal averages of interest rates and interest margins of banks in Spain (2004-2012)

\section{Background}

Ho and Saunders (1981) on a sample of the American banks developed a model in which the interest margin depends on four factors: the degree of risk aversion, the structure of the market, the average size of banking transactions and the variation of the interest rate applied to loans and deposits. Several authors have made extensions of this model by incorporating new variables and testing them with samples from several countries.

As some other features and results are synthetically presented in Table 1, we briefly mention that some of these contributions over the 1990s were Wong (1997), which contains an extended theoretical model, Angbazo (1997), which focuses on the American banks during the period 1989-1993, and DemirgüçKunt and Huizinga (1999), which is an international study using a large amount of variables.

Over the 2000s, several other contributions following the line of Ho and Saunders must be mentioned. The research by Saunders and Schmacher (2000) contains a study about several countries, including Spain, covering the period 1988-1995. Martinez Peric and Mody (2004) give special emphasis to highlighting differences regarding national and foreign banks in Latin American countries. As regards to the European financial institutions, Maudos and Fernandez de Guevara (2004) is another prominent example. Carbo Valverde and Rodriguez Fernandez (2007) do so for the period 1994-2001. Kasman, Tunc, Vardar and Okan (2010) also studied the case of European countries during the period 1995-2006.

More recently, Williams (2007) has emphasized the differences between domestic and foreign banks as regards to the Australian banks over the period 1989-2001. Hawtrey and Liang (2008) investigate the case in fourteen OECD countries during the period 1987-2001. Claeys and Vennet (2008) focus on European banks over the period 1994-2001. Also, Maudos and Solis (2009) do the same in the case of Mexico for the period 1993-2005, and Horvath (2009) examines the case of the Czech banks. The case of credit institutions in Eastern Europe is progressively gaining more and more attention, with new variables being tested, as indicated in Table 1. Schwaiger and Liebeg (2008) and Poghosyan (2010) are examples of this. Fungacova and Poghosyan (2011) focus on the Russian banks during the period 1999-2007.

De Yong and Tara (2004a, 2004b and 2004c) focus on several determinants affecting the evolution of incomes regarding US banks over the last decade of the twentieth century. In the first one, they mainly study how deregulation and technological change affected the capacity of those banks for obtaining incomes, whereas, in the second one, they specifically focus on the determinants of the increase registered in nonfinancial incomes. In the third article, some new factors potentially affecting the evolution of those nonfinancial incomes over the said period are tested.

Finally, Nguyen (2012) examines the case for 28 countries that experience financial liberalization reforms over the period 1997-2004; Lin, Chung, Hsieh, and Wu (2012) examined the period 19972005 in the case of the Asian banks.

Table 1 summarizes the variables tested in all of these articles also indicating the signs of regression coefficients obtained in each case, the R2 obtained for each of them, the period investigated, the area, and the econometric regression approach performed.

The above literature review also allows us to extract some other conclusions. On the one hand, we find that the weight interest margin has on total income has consistently diminished throughout the years in all the countries and, on the other hand, they also reveal that differences among countries are fewer and fewer. If the income obtained through the interest margin represented around $80 \%$ of total incomes in the early 1990s (Wong, 1996), over the 2000s, this source has represented only about half of total income on average. Obviously, other sources of income have seen their share increased in developed countries. Some examples of these other sources are: commissions, dividends, capital gains obtained from the selling of financial assets, income obtained from the selling of nonfinancial services and income coming from real estate speculative transactions, from investment in fixed and variable income securities. 


\section{Methodological issues}

2.1. Data and model. The sample used for our study is formed by all savings banks (47), as well as the most representative banks (14) operating in Spain at the beginning of the study (2004) together with all the new entities created as a result of the intense restructuring process implemented in the Spanish financial system over the last years (see Climent and Pavia, 2015). Credit institutions that make up the sample represent $95 \%$ of the total activity in Spain.

In particular, our study is based on the activity of a total of seventy-five credit entities over nine time periods: 2004-2012. For so doing, we have compiled a dataset of non-balanced panel data.

This allows for building a more informative database than databases just based on sectional information, because it presents more variability, less colinearity and more degrees of freedom, making it possible to take into account both the time and cross-sectional dimensions of the data by means of a non-balanced panel data econometric model. This, no doubt, will result in more efficient regression estimators and, overall, will allow us to better control for endogeneity and/or possible heterogeneity not individually observed.

The model has been estimated through the ordinary least squares (OLS) technique. As we use panel data, the Hausman's test has been employed for deciding which model is best fitted. As a result, we have chosen a model with fixed effects.

This also allows us to control for the possibility that each credit institution might have singular nonmeasurable, non-observable characteristics that might influence the relationship between interest margin and determinants. In our model, we have also introduced individual effects of the type: $\alpha_{i}=\alpha+v_{i}$. And have added some more variables than is usual in previous studies in order to obtain a more complete view of the various determinants potentially affecting the evolution of interest margins. Some of these variables might have been used as control variables (for example, the GDP). However, we decided to test the effect of these variables too for two main reasons: (i) firstly, for detecting the whole effect of all variables in a complete model that includes both internal variables (obtained from the balance sheet, the profits and losses account, etc.) and external ones (including variables of a different kind: some microeconomic, others of a macroeconomic nature), and (ii) second, for being able to extend the basic model and build some others containing interactions.

In particular, the model specification is as follows:

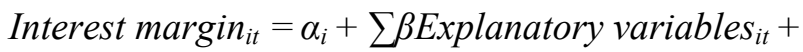

$+\omega_{i t}$.
2.2. Variables. The dependent variable is the interest margin, which is defined as the difference between interests paid and charged. Concerning the explanatory variables, in our model, we differentiate between explanatory variables that are internal to the credit entity from those that are external.

2.2.1. Internal variables. As internal variables, we have considered the following four groups: 1) structure of property, 2) extraordinary profits, 3) quality of the credit entity itself and 4) determinants obtained from the balance sheet information, both regarding assets and liabilities.

\section{A) Structure of the property}

Type: savings bank/bank. Dummy variable. For bank, we attribute a value of 1 , and for saving bank, a value of 0 . A positive sign for the coefficient would indicate that the interest margin is greater in banks.

\section{B) Determinants obtained from the balance sheet}

Liquidity/total assets. This ratio is formed by the most liquid assets as a share of total assets. As these types of assets do not generate incomes, the expected sign of this coefficient would be negative (Lin et al., 2012; Fungačova and Poghosyan, 2011).

Loans/total assets. Following Garcia-Herrero et al. (2009) and Kasman et al. (2010), we can expect higher interest margin the higher its loan portfolio is in relation to their total assets.

Deposits/total assets. This ratio is formed by the amount of deposits owed by credit institutions as a share of their total assets. As known, deposits represent a cheaper and more stable financial source than the alternatives (Claeys and Bennett, 2008; Garcia-Herrero et al., 2009). So, we expect a positive sign.

Own funds/total assets. This ratio is formed by the credit institutions own funds divided by their total assets. According to Ho and Saunders (1981), Angbazo (1997), Saunders and Schumacher (2000), Maudos and Fernandez de Guevara (2004), Williams (2007) and Solis Maudos (2009), Kasman et al. (2010), Fungačova, and Poghosyan (2011), Lin et al. (2012), negative sign is expected.

\section{C) Determinants from the incomes}

Capital yields/total assets. This is a ratio formed by the income obtained from investments in capital stocks divided by total assets.

Yields from financial operations/total assets. Income obtained by financial operations regarding the purchase and sale of all kinds of financial assets as a share of total assets.

Other operating income/total assets. This is the difference between income and cost stemming from non-financial activities as a share of total assets. 
By increasing investment in these three variables, investment in loans will decrease by decreasing the percentage of credits on the asset and, thus, the interest margin should decrease.

Net commissions/total assets. Income from commission as a share of total assets.

\section{D) Determinants from the expenditures-costs}

Administrative expenditures/total assets. This variable is measured as the sum of the administrative costs, including personnel, divided by total assets. The sign of this coefficient is expected to be positive, as greater material and professional capacity are often associated with better quality of services.

Efficiency ratio. This ratio results from dividing the cost of administration by the profit gross margin. The lower the ratio, the greater the efficiency of credit institutions. The expected sign of the coefficient would in this case be negative. According to Angbazo (1997), Maudos and Fernandez de Guevara (2004), Williams (2007), Maudos and Solis (2009) and Kasman et al (2010), we can expect that credit institutions with higher quality management will be able to perform a more efficient and profitable management.

\section{E) Extraordinary results}

Yields from the sale of assets/total assets. This variable represents the result obtained from the selling of assets as a share of total assets. The sign of the coefficient for this variable is undetermined, because it has no direct influence on the margin.

\section{F) Quality of the entity}

Non-performing loan rate. This delinquency rate shows the amount of non-performing loans as a share of total assets. Credit institutions that have a higher delinquency rate will be experiencing a reduction in the amount of interest received from these non-performing loans, which may affect negatively their interest margins. The sign of this variable will be negative.

Risk weighted assets ratio. This variable is the ratio upon which credit institutions calculate the minimum amount of resources needed to fill the solvency ratio. The price of the assets, i.e., the interest charged by credit institutions, is inversely related to the risk. By increasing the quality, the ratio decreases and the interest margin decreases.

Leverage ratio. This ratio is formed by the amount of loans given to customers divided by the amount of deposits obtained from customers. The entities with greater amount of loans we can expect higher interest margins.

\subsubsection{External variables.}

\section{A) Macro variables}

Consumer Price Index. Regarding prices, we use the Spanish consumer price index. It is expected that as inflation increases, the margin will increase (Martinez and Mody, 2004; Claeys and Vander, 2008; and Maudos and Solis, 2009).

Interest Rate (Euribor 12M). The expected sign, as Williams (2007) states, is positive, because the greater the 12-month Euribor, the greater the interest margin.

GDP rate of growth. This ratio refers to real GDP growth annual rate. In this case, the expected sign of the coefficient is positive.

\section{B) Micro variables}

Market power. This ratio is calculated, according to Nguyen (2012) and Williams (2007), as the squared ratio that is formed by the total amount of deposits of each entity divided by the total amount of deposits of the sector. The greater the market power, the higher the interest margin (Williams, 2007; Kasman et al., 2010; and Fungačova and Poghosyan, 2011). Therefore, the expected sign is positive.

Size. We calculate the size as the logarithm of total assets of the entity and its sign is negative. Increasing the size produces economies of scale and can reduce the margin.

\section{Results}

3.1. Descriptive results. Table 2 provides a descriptive summary of the variables tested, including the results obtained testing the differences between the means of banks and savings banks.

3.2. Econometric results. Table 3 presents the main results obtained through the regressions. We have checked for co-linearity and for correlation between variables and have found no problem. We have also performed two types of regressions. The first one using as explanatory factors the set of variables described in subsection 2.2. In the second regression, the ROA (return on assets) has been added as a new explanatory variable. The results found indicate that both models are good estimators of the interest margin of the Spanish credit institutions over the period studied, with an adjusted R2 that is greater than 0.90 in both cases. The statistical Durbin-Watson tells us that residuals show no autocorrelation. The model has been estimated considering fixed individual effects. The results obtained from the Hausman test guarantees the consistency and greater efficiency of the fixed individual effects estimator. 
Table 2. Descriptive summary of the interest margin determinants for the Spanish credit institutions (2004-2012)

\begin{tabular}{|c|c|c|c|c|c|c|c|c|c|c|c|c|}
\hline & \multicolumn{3}{|c|}{ All } & \multicolumn{3}{|c|}{ Savings bank } & \multicolumn{3}{|c|}{ Bank } & & & Dif S/B \\
\hline & Mean & Std. Dev. & $\mathrm{n}$ & Mean & Std. Dev. & $n$ & Mean & Std. Dev. & $\mathrm{n}$ & Gap & Sig. & \\
\hline Interest margin & $1.71 \%$ & $0.49 \%$ & \multirow{18}{*}{449} & $1.31 \%$ & $0.47 \%$ & \multirow{18}{*}{326} & $1.92 \%$ & $0.53 \%$ & \multirow{18}{*}{123} & $0.62 \%$ & $* * *$ & $B$ \\
\hline Liquidity & $8.15 \%$ & $1.18 \%$ & & $5.99 \%$ & $0.96 \%$ & & $9.33 \%$ & $1.59 \%$ & & $3.34 \%$ & $* * *$ & $B$ \\
\hline Loans/total assets & $63.44 \%$ & $8.07 \%$ & & $67.88 \%$ & $7.04 \%$ & & $61.00 \%$ & $10.26 \%$ & & $-6.88 \%$ & $* \star *$ & $S$ \\
\hline Deposits/total assets & $49.53 \%$ & $14.21 \%$ & & $58.28 \%$ & $11.23 \%$ & & $44.73 \%$ & $12.65 \%$ & & $-13.55 \%$ & $* \star * \star$ & $S$ \\
\hline Own funds/total assets & $5.48 \%$ & $2.41 \%$ & & $5.05 \%$ & $2.35 \%$ & & $5.72 \%$ & $2.57 \%$ & & $0.67 \%$ & $* *$ & $B$ \\
\hline Capital yields/total assets & $0.07 \%$ & $0.11 \%$ & & $0.11 \%$ & $0.12 \%$ & & $0.05 \%$ & $0.03 \%$ & & $-0.06 \%$ & $* \star * *$ & $S$ \\
\hline Net commissions/total assets & $0.65 \%$ & $0.20 \%$ & & $0.43 \%$ & $0.13 \%$ & & $0.78 \%$ & $0.24 \%$ & & $0.34 \%$ & $* \star \star *$ & $B$ \\
\hline Yields from financial operations/t.a. & $0.24 \%$ & $0.41 \%$ & & $0.25 \%$ & $0.24 \%$ & & $0.23 \%$ & $0.67 \%$ & & $-0.01 \%$ & & $S$ \\
\hline Other operating income/t.a. & $0.07 \%$ & $0.18 \%$ & & $0.12 \%$ & $0.17 \%$ & & $0.05 \%$ & $0.17 \%$ & & $-0.07 \%$ & $* \star * \star$ & $S$ \\
\hline Administrative expenditures/t.a. & $1.21 \%$ & $0.37 \%$ & & $1.08 \%$ & $0.35 \%$ & & $1.29 \%$ & $0.42 \%$ & & $0.20 \%$ & $* * *$ & $S$ \\
\hline Efficiency ratio & $44.03 \%$ & $14.44 \%$ & & $47.82 \%$ & $13.74 \%$ & & $42.47 \%$ & $15.99 \%$ & & $-5.35 \%$ & $* * *$ & $S$ \\
\hline Yields from the sale of assets/t.a. & $0.11 \%$ & $0.17 \%$ & & $0.11 \%$ & $0.17 \%$ & & $0.12 \%$ & $0.18 \%$ & & $0.01 \%$ & & $B$ \\
\hline Non-performing loans & $2.40 \%$ & $2.74 \%$ & & $3.03 \%$ & $2.84 \%$ & & $2.05 \%$ & $2.47 \%$ & & $-0.97 \%$ & $* * *$ & $\mathrm{~B}$ \\
\hline Risk weighted assets & $60.04 \%$ & $32.67 \%$ & & $59.47 \%$ & $32.75 \%$ & & $64.79 \%$ & $32.40 \%$ & & $5.33 \%$ & & $S$ \\
\hline Leverage ratio & $128.08 \%$ & $31.38 \%$ & & $116.48 \%$ & $20.31 \%$ & & $136.37 \%$ & $38.52 \%$ & & $19.89 \%$ & $* \star \star *$ & $B$ \\
\hline Market power & $0.003 \%$ & $0.018 \%$ & & $0.001 \%$ & $0.002 \%$ & & $0.010 \%$ & $0.033 \%$ & & $0.010 \%$ & $* \star * \star$ & $B$ \\
\hline Size of activities & 16.60 & 1.58 & & 16.34 & 1.39 & & 17.31 & 1.83 & & 0.97 & $* * *$ & $\mathrm{~B}$ \\
\hline $\mathrm{ROA}$ & $0.69 \%$ & $1.75 \%$ & & $0.30 \%$ & $1.59 \%$ & & $0.91 \%$ & $2.12 \%$ & & $0.61 \%$ & $* * *$ & $B$ \\
\hline
\end{tabular}

In addition, in order to take into account potential differences between different types of entities, we have also analyzed whether the impact of each determinant is more different in savings banks than in banks. To do this, we have estimated the same previous model, but additionally introduced the interaction each component has with the variable type. If the coefficient we estimate in the model with interactions appears significant for a factor, this means that the impact of this factor upon banks and savings banks interest margins is not the same. If positive, this would indicate that the impact in the case of banks is higher than in the case of savings banks and vice versa. If the coefficient shows up nonsignificant, this would indicate that there are no differences in the role each determinant plays in the case of banks versus savings banks.

3.2.1. Structure of the property. In the first model, the dummy variable has proved to be significant and with a positive sign, which indicates that under similar circumstances, banks obtain a higher interest margin than savings banks. This finding is consistent with the fact that most public funding used for the financial bailouts in Spain was directed to the savings banks.

Table 3. Regression models

\begin{tabular}{|c|c|c|c|c|c|c|}
\hline & Variables & Base & With ROA & \multicolumn{2}{|c|}{ With interactions } & Elasticity \\
\hline & \multirow{2}{*}{ Constant } & 0.014 & 0.013 & $0.017^{\star \star \star}$ & & \\
\hline & & $(0.009)$ & $(0.009)$ & $(0.001)$ & & \\
\hline \multirow{2}{*}{ Structure of the property } & \multirow{2}{*}{ Savings bank - bank } & $0.004^{* *}$ & $0.004^{* *}$ & & \multirow{2}{*}{ Bank } & \\
\hline & & $(0.002)$ & $(0.002)$ & & & \\
\hline \multirow{8}{*}{ Balance sheet } & \multirow{2}{*}{ Liquidity/total assets } & 0.011 & 0.011 & -0.009 & & \multirow{2}{*}{0.011} \\
\hline & & $(0.009)$ & $(0.009)$ & $(0.022)$ & & \\
\hline & \multirow{2}{*}{ Loans/total assets } & 0.003 & 0.003 & 0.005 & & \multirow{2}{*}{0.129} \\
\hline & & $(0.003)$ & $(0.003)$ & $(0.009)$ & & \\
\hline & \multirow{2}{*}{ Deposits/total assets } & $0.008^{\star \star}$ & $0.008^{* \star}$ & 0.011 & & \multirow{2}{*}{0.315} \\
\hline & & $(0.003)$ & $(0.003)$ & $(0.011)$ & & \\
\hline & \multirow{2}{*}{ Own funds/total assets } & 0.008 & 0.008 & 0.020 & & \multirow{2}{*}{0.029} \\
\hline & & $(0.007)$ & $(0.007)$ & $(0.023)$ & & \\
\hline \multirow{8}{*}{ Incomes } & \multirow{2}{*}{ Capital yields/total assets } & $-0.453^{\star \star \star}$ & $-0.453^{\star \star \star}$ & 0.2776 & & \multirow{2}{*}{-0.023} \\
\hline & & $(0.127)$ & $(0.127)$ & $(0.870)$ & & \\
\hline & \multirow{2}{*}{ Net commissions/total assets } & $-0.224^{*}$ & $-0.223^{*}$ & 0.173 & & \multirow{2}{*}{-0.066} \\
\hline & & $(0.116)$ & $(0.116)$ & $(0.285)$ & & \\
\hline & \multirow{2}{*}{ Yields from financial operations/t.a. } & $-0.126^{\star \star *}$ & -0.127 & $-0.077^{*}$ & \multirow{2}{*}{ Savings bank } & \multirow{2}{*}{-0.018} \\
\hline & & $(0.022)$ & $(0.023)$ & $(0.044)$ & & \\
\hline & \multirow{2}{*}{ Other operating income/total assets } & $-0.265^{\star}$ & $-0.267^{\star \star \star}$ & $-0.581^{* \star *}$ & \multirow{2}{*}{ Savings bank } & \multirow{2}{*}{-0.018} \\
\hline & & $(0.057)$ & $(0.058)$ & $(0.187)$ & & \\
\hline
\end{tabular}


Table 3. (cont.) Regression models

\begin{tabular}{|c|c|c|c|c|c|c|}
\hline & Variables & Base & With ROA & With & eractions & Elasticity \\
\hline \multirow{4}{*}{ Expenditures-costs } & \multirow{2}{*}{$\begin{array}{l}\text { Administrative expenditures/total } \\
\text { assets }\end{array}$} & $1.023^{\star \star \star}$ & $1.027^{\star * \star}$ & $0.919^{* \star *}$ & \multirow{2}{*}{ Bank } & \multirow{2}{*}{0.803} \\
\hline & & $(0.071)$ & $(0.073)$ & $(0.190)$ & & \\
\hline & \multirow{2}{*}{ Efficiency ratio } & $-0.010^{* * *}$ & $-0.010^{* * *}$ & $-0.006^{* *}$ & \multirow{2}{*}{ Savings bank } & \multirow{2}{*}{-0.313} \\
\hline & & $(0.001)$ & $(0.001)$ & $(0.003)$ & & \\
\hline \multirow{2}{*}{ Extraordinary results } & \multirow{2}{*}{$\begin{array}{l}\text { Yields from the sale of assets/total } \\
\text { assets }\end{array}$} & $-0.107^{\star \star}$ & $-0.108^{* *}$ & -0.103 & & \multirow{2}{*}{-0.007} \\
\hline & & $(0.047)$ & $(0.047)$ & $(0.135)$ & & \\
\hline \multirow{6}{*}{ Quality of the entity } & \multirow{2}{*}{ Non-performing loan ratio } & $-0.031^{* \star *}$ & $-0.031^{* * *}$ & -0.023 & & \multirow{2}{*}{-0.042} \\
\hline & & $(0.007)$ & $(0.007)$ & $(0.017)$ & & \\
\hline & \multirow{2}{*}{ Risk weighted assets } & $-0.002^{* *}$ & $-0.002^{* *}$ & -0.002 & & \multirow{2}{*}{-0.033} \\
\hline & & $(0.001)$ & $(0.001)$ & $(0.002)$ & & \\
\hline & \multirow{2}{*}{ Leverage ratio } & $0.003^{\star \star \star}$ & $0.003^{\star * \star}$ & 0.004 & & \multirow{2}{*}{0.208} \\
\hline & & $(0.001)$ & $(0.001)$ & $(0.003)$ & & \\
\hline \multirow{6}{*}{\begin{tabular}{|l} 
External macro \\
variables
\end{tabular}} & \multirow{2}{*}{ Consumer Price Index } & 0.008 & 0.008 & 0.015 & & \multirow{2}{*}{0,013} \\
\hline & & $(0.016)$ & $(0.016)$ & $(0.042)$ & & \\
\hline & \multirow{2}{*}{ Interest rate } & $0.046^{* \star *}$ & $0.046^{* \star *}$ & 0.036 & & \multirow{2}{*}{0,076} \\
\hline & & $(0.011)$ & $(0.011)$ & $(0.029)$ & & \\
\hline & \multirow{2}{*}{ GDP rate of growth } & $-0.071^{* \star *}$ & $-0.071^{* \star *}$ & $-0.087^{\star \star \star}$ & \multirow{2}{*}{ Savings bank } & \multirow{2}{*}{0,063} \\
\hline & & $(0.013)$ & $(0.013)$ & $(0.0327)$ & & \\
\hline \multirow{13}{*}{ Micro variables } & \multirow{2}{*}{ Market power } & $4.686^{* \star \star}$ & $4.672^{\star \star \star}$ & $5.112^{\star \star \star}$ & \multirow{2}{*}{ Bank } & \multirow{2}{*}{0,009} \\
\hline & & $(0.955)$ & $(0.958)$ & $(1.546)$ & & \\
\hline & \multirow{2}{*}{ Size of activities } & $-0.001^{*}$ & -0.001 & $-0.002^{\star \star \star}$ & ASavings hank & $-0,060$ \\
\hline & & $(0.000)$ & $(0.000)$ & $(0.000)$ & joavings Darin & $-0,000$ \\
\hline & $\mathrm{ROA}$ & & 0.002 & 0.019 & & ( \\
\hline & & & $(0.007)$ & $(0.018)$ & & 0,001 \\
\hline & & panel (unbal & ervations: 44 & & & \\
\hline & Cross-sections included: 75 & Peri & $\mathrm{d}: 9$ & $\mathrm{~N}=449$ & & \\
\hline & Adjusted R-squared & 0,908839 & 0,908595 & 0,800514 & & \\
\hline & Durbin-Watson stat & 1,806227 & 1,806516 & 1,629401 & & \\
\hline & & evels: *** $1 \mathrm{pe}$ & percent; ${ }^{*} 10$ & & & \\
\hline & & Standard erro & arentheses & & & \\
\hline & Method: & ast Squares. & ion fixed (dur & iables) & & \\
\hline
\end{tabular}

3.2.2. Balance sheet. Concerning the balance sheet variables, only one of them has proved to be significant: the ratio deposits/total assets. And the sign of the coefficient is positive. Lower weight of deposits in total assets is associated with lower interest margin. As known, the weight deposits have in total assets is being decreased since the mid-1990s, in part due to the greater access these entities have to international wholesale markets. This means that interest margin has evolved in the same direction, negatively affecting profitability of Spanish credit institutions. The evolution of this ratio from the balance sheet over the period examined contributed to the severe financial crisis registered in Spain.

3.2.3. Incomes. Regarding the income variables. The four variables studied (capital gains, commissions, profits from financial operations, and other operating income) have proved to be significant and with a negative sign. This means that greater diversification regarding the income sources translates to lower interest margin. Therefore, we can conclude that even if a structural change consisting of a greater diversification of income sources has taken place, this has not prevented the reduction registered in the interest margin of Spanish credit institutions over the period examined.

3.2.4. Expenditures-costs. The results we have obtained concerning the expenditures-costs related variables are interesting too. The two variables studied appear significant. The sign for the efficiency rate has come out to be negative. Greater efficiency ratios are then, associated with lower interest margins, although the coefficient is very small $(-0.010)$. In this case, our conclusion is in line with those of Maudos et al. (2004), Williams (2007), Claeys and Bennett (2008), Schwaiger et al. (2008), Hawtrey and Liang (2008), Maudos and Solis ( 2009), Kasman et al. (2010).

The result obtained as regards to administration costs is also informative. The sign of the coefficient here is positive and its magnitude is the biggest one of all the variables we have tested as share of total assets (1.023). Therefore, higher costs of administration, including personnel, appear associated with substantially higher interest margins. 
As an intensive reduction in personnel has taken place over the period studied, this costs savings facilitates the reduction of the interest margin of credit institutions, then contributing to increase competitiveness of the Spanish economy if firms get external financial resources at a lower cost. However, the significant reduction in jobs that has taken place as a result of the already mentioned bailouts and restructuring represents a negative factor for the future profitability of these entities if our positive correlation between administrative costs, including personnel, and interest margin remains in the future.

3.2.5. Extraordinary results. The result obtained for the coefficient on the sale of assets, a variable that has received little or no attention in the literature, seems also very informative. It has proved to be significant and with a negative sign, with a coefficient of -0.107 . This means that the greater the yields obtained from these purchasing and selling of non-ordinary assets the lower the interest margin. When the non-financial activities provide significant amounts of yields, as happens over the growth periods, credit entities can shorten interest margins.

3.2.6. Quality of the entity. The variable measuring the delinquency rate has also proved to be significant and with a negative sign, with a coefficient of 0.031 . Higher ratios are significantly associated with lower interest margins. An increase in the delinquency ratio means that some interest rates from debtors will not be realized, which negatively affects the interest margin finally obtained.

As previously mentioned, another singular variable that is often mentioned in the literature, but not tested, is the one referring to the quality of assets measured according to their risk. In our case, this variable has proved to be significant and with a negative sign, so that the lower the ratio (less risk or higher quality of assets), the higher the interest margin.

The leverage rate is another singular variable here tested that has received little attention in the literature. In our research it has proved to be significant and with a positive sign, so a higher leverage rate is associated with a greater interest margin. However, an increase of this rate also increases some other risks confronted by the credit entities when circumstances get suddenly altered and these entities cannot renew their external funding from international wholesale markets or when their assets drastically see their market value reduced, for example. This is exactly what has happened in the case of several Spanish saving banks since the 2008 financial crash. Of course, the risks associated to higher leverage rates are lower, as higher is the quality of assets of those credit entities accessing international financial markets.
3.2.7. External macro variables and micro variables. Regarding the external variables. First, the Consumer Price Index has proved to be nonsignificant, though with a positive sign. Regarding the Euribor, it has shown to be significant and with a positive sign, as expected. Therefore, the higher the Euribor, the greater the interest margin of Spanish credit institutions. Finally, concerning GDP, our study shows a negative sign and a significant variable. This sign of the coefficient has also been found by Carbo et al. (2007), Claeys and Vennet (2008), as well as Kasman et al. (2010) and Tarus et al. (2012). Over periods with significant GDP growth, credit entities may decide to reward deposits with higher interest rates to capture more savings to meet the increased demand for credits they receive over those years, and may also reduce the interest rate charged on loans because of the lower delinquency rate.

The variable that measures market power has proved to be significant and with a positive sign: an increase in market power translates into an increase in interest margin.

Although these variables might have been included in the model as control variables, we decided not to proceed that way and treat them instead as potential determinants in order to study the effect of interactions. We have done so when searching for differences between banks and savings banks. Our results are in line with expectations.

\subsection{Differences between banks and savings banks.} Through our model with interactions, we have found that seven variables are significant. This means that in our sample, a similar variation in the regress or does not produce the same impact on the interest margin of the banks than that of savings banks. For five of these variables, the impact appears greater in the case of savings banks. Only in two cases, the impact is greater for banks than for savings banks.

Two income variables are relevant and with a negative sign: yields from financial operations and other operating income. This means that a similar increase of these two variables in our sample produces a sharper decrease in the case of savings banks than in banks. In the case of other operating income, the coefficient is quite important $(0.581)$, which means that a similar increase in this variable results in a decrease of the interest margin 58\% higher for savings banks than for banks.

Concerning those determinants linked to expenditures-costs, in our model with interactions, the costs of administration are significant, but with a positive sign. Therefore, a similar increase in these costs in our sample results in a greater increase of the interest rate in banks than in savings banks. As the coefficient is about 0.919 , this increase is almost a hundred per cent higher in the case of banks. The effi- 
ciency variable has proved to be significant and with a negative sign. Lower efficiency ratios are associated with greater decreases in the interest margin in savings banks than in banks.

Regarding the external factors, GDP growth has been significant and with a negative sign. In this case, an increase of GDP is significantly associated with a greater reduction of interest margin in the case of savings banks. Finally, two variables have proved to be statistically significant too, regarding the internal variables tested. In the case of market power, the sign is positive, so higher market power levels in our sample get associated with higher interest margins too, but the impact is higher again for banks than for savings banks. However, the variable referring to size has resulted in a negative sign, so an increase in the size of credit institutions gets associated with a bigger decrease of interest margin in the case of savings banks.

Therefore, the above results clearly indicate that in our sample there are significant differences regarding the impact each determinant has upon savings banks and banks regarding their interest margins.

\section{Conclusion}

The financial crash that took place in 2007-2008 and the subsequent economic recession has led many credit institutions worldwide to bankruptcy or to be bailedout and restructured or merged. This has also affected the weight interest margin has on total income.

Though we have followed Ho and Saunders (1981), the model here developed has included three singular determinants that have received little attention in the literature: their rate of leverage, the quality of their total assets measured according to their risk, and the profit obtained from the selling of assets, including real state ones. We have also found some differences regarding banks and savings banks. The following are our main concluding remarks.

Concerning the management of the balance sheet, the most important conclusion obtained is that the change in strategy implemented by the Spanish credit institutions since the mid-1990s (in an attempt to keep their high rate of growth thanks to a greater access to the international wholesale financing) led them to experience a lower interest margin and, consequently, lower profitability over the years studied. Now that the economy seems to be initiating a new, though very incipient, recovering phase at national and international levels, paying attention to our findings and advancing some regulatory measures to prevent such over financing at international wholesale markets seems quite reasonable.

Concerning the degree of diversification of income sources, our research allows us to find that greater diversification gets significantly correlated with lower interest margins. The coefficients of the four types of incomes included in this variable indicate that the more the income Spanish entities get from non-traditional lending sources the lower the interest margin. As shorter interest margins mean greater competitiveness on the part of these financial entities in doing their intermediary functions for channeling savings to investments, greater diversification of sources has meant in the Spanish case lower interest rates charged to borrowers.

As known, the restructuring of credit institutions made in Spain, as well as in other EU countries, required those entities, which got some financial aid to disinvest in non-lending traditional activities, and particularly in real estate assets. As a result, our study allows us also to predict that in the coming years, once the recession gets finally passed, these entities will not be able to get again the significant amount of income they got from this source before 2008. Interest margin will see its share of total income increased. Their profitability will depend more heavily on their traditional lending operations and the cost savings they are able to achieve. If this process finally ends in higher interest margins, this could impact negatively on their competitiveness and the interest rates they charge to borrowers, though this result is not inevitable, of course.

Our research has also allowed us to conclude that higher administrative costs, including personnel, are significantly correlated with higher interest margins. As the restructuring process is also leading to a significant reduction in personnel and other operating costs, these cost saving measures might serve to moderate the above mentioned expected increase in interest margins and interest rates once solvent demand for credit significantly recovers itself. As mentioned in the paper, we can also conclude that this intensive reduction in personnel costs may lead to two different scenarios in the coming years. On the one hand, the reduction of such costs does in fact help to reduce interest rates charged to credits, even with a similar interest margin, then, contributing to increase competitiveness of the Spanish economy, as firms may obtain external financial resources at a lower cost. On the other hand, the significant reduction in jobs as a result of bailouts and restructuring represents a negative factor in the medium term, if our positive correlation between the evolution of administrative costs, including personnel, and the evolution of interest margin remains in the future.

If we take into account that the delinquency ratio of Spanish credit institutions is increasing very rapidly, our study also allows us to stress that this factor may be impacting negatively upon their interest margin. The quality of assets, measured according to their risk, has also proved to be a significant determinant. 
The lower this ratio (higher quality of assets), the greater the associated interest margin. The losses resulting from these risky assets (even if interest rates charged are higher) seem to be more important for interest margins and profitability than the impact derived from the lower interest rates that are charged to less risky assets.

Though a high and increasing leverage rate on the part of the credit entities is often considered as a key factor influencing the severity of any financial crisis, our study allows us to qualify the argument, because the consequences of a specific leverage rate depend on a variable that has in fact been taken into account in our study with relevant results. This variable is the risk associated to each leverage rate, which is inversely dependent on the quality of assets measured with the usual risk weighted assets ratio. Our study shows that an increase in this ratio is positively associated with an increase in interest margin. Therefore, a similar increase in the leverage ratio of credit entities will influence less negatively over the crisis periods, as higher is the quality of assets of these entities, ceteris paribus.

The external variables (those that might have been taken as control variables, but were not for the reason already mentioned) impact as expected. Higher interest rates, higher GDP rate of growth and higher market power get positively associated with higher interest margin in our study over the period examined. By contrast, an increase in the size of the activities gets positively associated with a lower interest margin, which is consistent with the well-known economies of scale.
Finally, the study also indicates that the structure of ownership (savings bank versus bank) is also a relevant determinant. The banks in our sample present a higher interest margin than the savings banks. In fact, in our model with interactions, all variables that have a significant and negative correlation with the interest margin (yields from financial operations, other operating income, efficiency ratio, GDP rate of growth, and size of the entity) show (negative) greater correlation impact on the interest margin of savings banks than in that of banks. On the contrary, for the two variables (administrative costs, including staff, and market power) in which a significant and positive correlation exists, we have found that the impact regarding interest margins is greater (and positive) for banks than for savings banks.

These results are consistent with the fact that in Spain, most of the financial aid used for bailouts and restructuring of the financial system has been directed to the savings banks. As mentioned, we are not alone regarding these differential impacts the financial crisis has produced upon banks and savings banks, as they have also been found by other authors. In a context of more and more competitive global financial markets, the future profitability of this type of entities is at greater risk. Therefore, our results may be of particular interest for those countries where entities similar to the Spanish savings banks still have a significant market share, as is the case of Germany, for instance.

\section{References}

1. Angbazo, L. (1997). Commercial bank net interest margins, default risk, interest-rate risk, and off-balance sheet banking. Journal of Banking \& Finance, 21, 55-87. http://dx.doi.org/10.1016/S0378-4266(96)00025-8

2. Carbo-Valverde, S., and Rodriguez-Fernandez, F. (2007). The determinants of bank margins in European banking. Journal of Banking \& Finance, 31, 2043-2063. http://dx.doi.org/10.1016/j.jbankfin.2006.06.017

3. Claeys, S., and Vennet, R. V. (2008). Determinants of bank interest margins in Central and Eastern Europe: A comparison with the West. Economic Systems, 32, 197-216. http://dx.doi.org/10.1016/j.ecosys.2007.04.001

4. Climent-Serrano, S., and Pavia, J. M. (2015). Determinants of profitability in Spanish financial institutions. Comparing aided and non-aided entities. Journal of Business Economics and Management, 16(6), 1170-1184. http://dx.doi.org/10.3846/16111699.2013.801881

5. Demirgüç, A., and Huizinga, J. H. (1999). Determinants of Commercial Bank interest margins and tracking sales: Some International Evidence. World Bank Economic Review, 13, 379-408.

6. DeYoung, Robert, and Tara, Rice. (2004). How do Banks make Money? the Fallacies of Fee Income. Federal Reserve Bank of Chicago Economic Perspectives, 28(4), 34-51.

7. DeYoung, Robert, and Tara, Rice. (2004). Noninterest Income and Financial Performance at U.S. Commercial Banks. Financial Review, 39(1), 101-127.

8. DeYoung, Robert, and Tara, Rice (2004). How do Banks make Money? A Variety of Business Strategies. Federal Reserve Bank of Chicago Economic Perspectives, 28(4), 52-67.

9. Fungačova, Z., and Poghosyan, T. (2011). Determinants of bank interest margins in Russia: Does bank ownership matter? Economic Systems, 35, 481-495. http://dx.doi.org/10.1016/j.ecosys.2010.11.007

10. Garcia Herrero, A., Gavila, S., and Santabárbara, D. (2009). What explains the low tracking salesrep of Chinese banks. Journal of Banking \& Finance, 33, 2080-2092. http://dx.doi.org/10.1016/j.jbankfin.2009.05.005

11. Hawtrey, K., and Liang, H. (2008). Bank interest margins in OECD countries. North American Journal of Economics and Finance, 19, 249-260. http://dx.doi.org/10.1016/j.najef.2008.07.003

12. Ho, A., and Saunders, A. (1981). The determinants of bank interest margins: theory and empirical evidence. Journal of Financial and Quantitative Analysis, XVI(4), 581-600. http://dx.doi.org/10.2307/2330377 
13. Horvath, R. (2009). The determinants of the interest rate margins of Czech banks. Czech Journal of Economics and Finance, 59, 128-136. Retrieved from http://journal.fsv.cuni.cz/storage/1154_1154_horvath.pdf

14. Kasman, A., Tunc, G., Vardar, G., and Bern, O. (2010). Consolidation and commercial bank net interest margins: Evidence from the old and new European Union members and candidate countries. Economic Modeling, 27, 648655. http://dx.doi.org/10.1016/j.econmod.2010.01.004

15. Lin, J. R, Chung, H., Hsieh, H. H., and Wu, S. (2012). The determinants of interest margins and their effect on bank diversification: Evidence from Asian banks. Journal of Financial Stability, 8, 96-106. http://dx.doi.org/10.1016/j.jfs.2011.08.001

16. Martínez, M. S., and Mody, A. (2004). How foreign participation and market concentration impact bank spreads: evidence from Latin America. Journal of Money, Credit and Banking, 3, 511-537. Retrieved from http://www.jstor.org/stable/3838950

17. Maudos, J., and Fernádez of Guevara, J. (2004). Factors explaining the interest margin in the banking sectors of the European Union. Journal of Banking \& Finance, 28, 2259-2281. http://dx.doi.org/10.1016/j.jbankfin.2003.09.004

18. Maudos, J., and Solis. (2009). The determinants of net interest income in the Mexican banking system: an integrated model. Journal of Banking \& Finance, 33, 1920-1931. http://dx.doi.org/10.1016/j.jbankfin.2009.04.012

19. Nguyen, J. (2012). The relationship between net interest margin and noninterest income using a system estimation approach. Journal of Banking \& Finance, 36, 2429-2437. http://dx.doi.org/10.1016/j.jbankfin.2012.04.017

20. Poghosyan, T. (2010). Re-examining the impact of foreign bank participation on interest margins in emerging markets. Emerging Markets Review, 11, 390-403. http://dx.doi.org/10.1016/j.ememar.2010.08.003

21. Saunders, A., and Schumacher, L. (2000). The determinants of bank interest rate margins: an international study. Journal of International Money and Finance, 19, 813-832. http://dx.doi.org/10.1016/S0261-5606(00)00033-4

22. Schwaiger, M., and Liebeg, D. (2008). Determinants of bank interest margins in Central and Eastern Europe. OENB Financial Stability Report, Austrian National Bank, Vienna.

23. Williams, B. (2007). Factors determining net interest margins in Australia: domestic and foreign banks. Financial Markets, Institutions and Instruments, 16, 145-165. http://dx.doi.org/10.1111/j.1468-0416.2007.00122.x

24. Wong, K. P. (2008). On the determinants of bank interest margins under credit and interest rate risks. Journal of Banking \& Finance, 21, 251-271. http://dx.doi.org/10.1016/S0378-4266(96)00037-4 
Table 1. Summary of the main characteristics of contributions reviewed

\begin{tabular}{|c|c|c|c|c|c|c|c|c|c|c|c|c|c|c|c|c|c|c|c|c|c|c|c|c|c|c|c|c|c|c|c|c|c|c|c|c|c|c|c|c|c|c|c|}
\hline & & 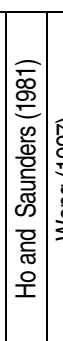 & & & 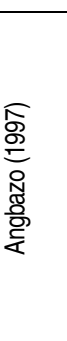 & & & & 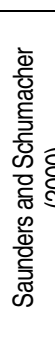 & & & & 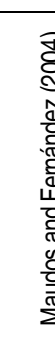 & & & 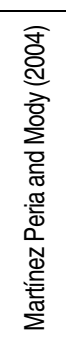 & & & 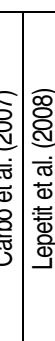 & 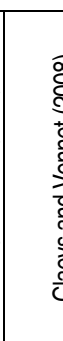 & 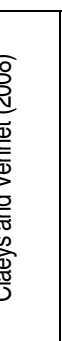 & 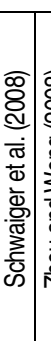 & 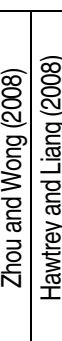 & 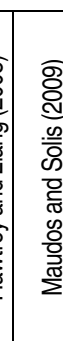 & & & & 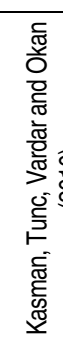 & & & & 를 & & & 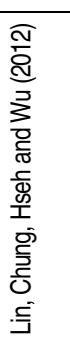 & & & & & & 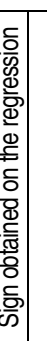 & & \\
\hline \multirow{2}{*}{\begin{tabular}{l|} 
Structure of \\
the property
\end{tabular}} & Saving bank - bank & & & & & & & & & & & $=$ & \begin{tabular}{l|l}
$b$ & $b$ \\
\end{tabular} & $b$ & \begin{tabular}{l|l}
$b$ & $b$ \\
\end{tabular} & $\mathrm{~b}$ & \begin{tabular}{l|l}
$\mathrm{b}$ & $\mathrm{a}$ \\
\end{tabular} & & & & & $\mathrm{s}$ & & & & & & & & & - & & & & & & & & & & $\mathrm{b}$ & & \\
\hline & National - foreign & & & & & & & & & & & 4 & & & $\mathrm{e}$ & 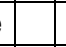 & 1 & n & & & & $\mathrm{e}$ & & & & $\mathrm{e}$ & e & & & & & & & & & & & & & & & & \\
\hline \multirow{4}{*}{$\begin{array}{l}\text { Balance } \\
\text { sheet }\end{array}$} & Liquidity/total assets & $i$ & & - & - & & + & + & $(+)$ & + & + & - & + & + & + & & ( & $(-)+$ & + & 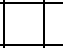 & & - & ++ & $(+)$ & $(+)$ & $(+$ & $+)$ & 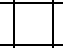 & & + & - & - & & 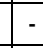 & $+(-)$ & & ( & $(-)$. & - & & 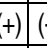 & c & \\
\hline & Loans / total assets & & & & & 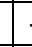 & & & & & & + & ++ & 1 & + & & & - & - & ++ & $+(+)$ & + & ++ & $i$ & $(+)$ & + & + & + & ++ & + & 7 & & & & $\square$ & - & \begin{tabular}{|l|}
- \\
\end{tabular} &..- & T & + & 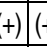 & $B$ & \\
\hline & Deposits / total assets & & & & & & & 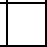 & & 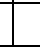 & 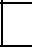 & & & 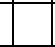 & & & & 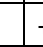 & + & $+1+$ & $+(+)$ & & & $(+)$ & $(-)$ & 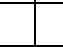 & 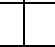 & $\frac{1}{1}$ & (1 & T & 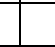 & 1 & & & + & 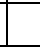 & T & 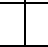 & 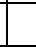 & + & $+(-1-1)-x$ & E & \\
\hline & Own funds / total assets & + & & $+)+$ & $(+)$ & & + & + & $(+)\left(\begin{array}{ll}(-1 & -r\end{array}\right.$ & + & $(+)$ & & + & + & $++(+$ & ). $(+)$ & $(+)$ & + & + & +1 & ++ & + & - & + & + & $(-)+$ & ++ & - & $(-)+$ & ++ & ++ & + & & + & ++ & + & + & ++ & + & & 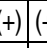 & E & \\
\hline \multirow{5}{*}{ Incomes } & $\begin{array}{l}\text { Capital yields /total } \\
\text { assets }\end{array}$ & & & & & & & & & & & & & & & & & & & & & & & & & & & & & & & & & & & & & & & . & - & B & \\
\hline & \begin{tabular}{|l|}
$\begin{array}{l}\text { Net commissions/total } \\
\text { assets }\end{array}$ \\
\end{tabular} & & & & & & & & & & & & & & & & & H & t) & & & & & $(-)$ & & (+) - & & & & & & & & & & & & & & $i$ & - & B & \\
\hline & $\begin{array}{l}\begin{array}{l}\text { Yields from financial } \\
\text { operations/t.a. }\end{array} \\
\end{array}$ & & & & & & & & & & & & & & & & & & $(-)$ & & & & & - & - & & & & & & & & & & & & & & & . &. & $\mathrm{s}$ & \\
\hline & \begin{tabular}{|l|}
$\begin{array}{l}\text { Other operating } \\
\text { incomeltotal assets }\end{array}$ \\
\end{tabular} & & & & & & & & & & & & & & & & & & - & & & & & $\cdot$ & $(-)$ & & & & & & & & & & & & & & & - &. & $\mathrm{s}$ & \\
\hline & \begin{tabular}{|l|} 
Implicit interest \\
payments:
\end{tabular} & & & ++ & + & & $1+$ & $(+)$ & $(+)$ & + & + & + & ++ & + & + & & & + & - & & & + & ++ & + & + & & $-1+$ & + & ++ & + & & & & + & ++ & & & & & - & & & \\
\hline \multirow{2}{*}{$\begin{array}{l}\text { Expenditur } \\
\text { es-costs }\end{array}$} & $\begin{array}{l}\text { Administrative } \\
\text { expenditures/t.a. }\end{array}$ & & + & & & & & & & & & + & ++ & + & ++ & + & + & + & $(+)$ & & & + & ++ & + & + & ++ & ++ & + & ++ & ++ & ++ & + & & & & - & 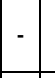 & - & + & + & + & B & \\
\hline & Efficiency ratio & & & ++ & $(+)$ & & & & & & & -1 & - & - & - & & 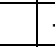 &.- & + & . & $(-)$ & & + & - & - & + & + & - & 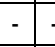 & - & & & & + & $(+)(-)$ & & & & 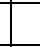 & - &.- & $s$ & \\
\hline Ext. results & $\begin{array}{l}\text { Yields from the sale of } \\
\text { assets/t.a. }\end{array}$ & & & & & & & & & & & & & & & & & & & & & & & & & & & & & & & & & & & & & & & . & ( & $\mathrm{s}$ & \\
\hline \multirow{3}{*}{$\begin{array}{l}\text { Quality of } \\
\text { the entity }\end{array}$} & \begin{tabular}{|l} 
Non-performing loan \\
ratio
\end{tabular} & & + & $+(+)$ & ) $(-)$ & & & & & & & & & & +0 & $\Rightarrow(+)$ & $(-)$ & -3 & ++ & & & & & + & + & + & ++ & $(-)$ & (+) & - & $+(+)$ & - & & + & $+(+)$ & + & $(+)$ & $+(+$ & + & $i$ & ( & $S$ & \\
\hline & Risk weighted assets & & & & & & & & & & & & & & & & & & & & & & & & & & & & & & & & & & & & & & & \pm & $-16 \quad r$ & 5 & \\
\hline & Leverage ratio & & & & & & & & & & & & & & & & & & & & & & & & & & 1 & 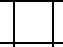 & & & & & & & 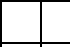 & & & & 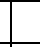 & $i$ & $+(-1-r)$ & E & \\
\hline \multirow{3}{*}{ External } & Consumer Price Index & & & & & & & & & & & & & & $(--1)$ & $-(-)$ & $(+)$ & & & $+1-1$ & $+(+)$ & & & & & ++ & ++ & $(+)$ & $+(t$ & +) & & & & & 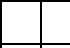 & & & & + & $i$ & 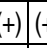 & B & \\
\hline & Interest rate & + & + & & & & & & & & & + & $-1+$ & + & + & & & +) & ++ & +1 & $+(-)$ & + & & & & + & + & 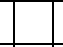 & & & & & & + & $-(+)$ & & & & & + & $+(-1-r)$ & E & \\
\hline & GDP rate of growth & & & & & & & & & & & & & & $(+$ & t) $(+)$ & $(+)$ & 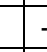 & - & +6 & $-1-$ & + & + & + & & $(+)+$ & + & $(+)$ & $\cdot(t$ & $(+)$ & & & & & & & & & $(+)$ & + &.- & $s$ & \\
\hline \multirow{2}{*}{\begin{tabular}{|l|} 
Micro \\
variables
\end{tabular}} & Market power & - & + & & & & & & & & & + & ++ & + & $+(-)$ & & + & & +) $(+)$ & $(-)(-H)$ & +) $(-)$ & + & & + & + & $+(+$ & +) + & + &.+ & 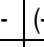 & $-)+$ & $(-)$ & & & & + & + & ++ & + & + & +- & E & \\
\hline & Size of activities & - & & & & & 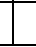 & & & & & -1 &.+ & + & \begin{tabular}{l|l}
- & \\
\end{tabular} & & & + & & & & $(-)$ & \begin{tabular}{l|l}
- & - \\
\end{tabular} & & + & $-1+$ & 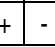 & -1 & -1. & & +5 & \begin{tabular}{|l|l}
- & \\
\end{tabular} & - & & & & & + +).- & & - & -1. & $s$ & \\
\hline
\end{tabular}




\begin{tabular}{|c|c|c|c|c|c|c|}
\hline 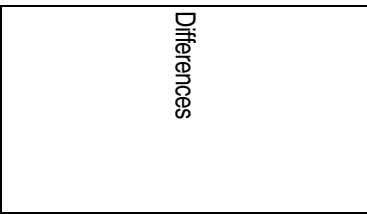 & 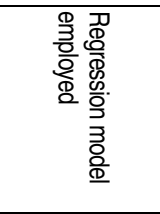 & $\begin{array}{l}\text { D } \\
\mathbb{D} \\
\mathbb{D}\end{array}$ & $\begin{array}{l}\text { T. } \\
\text { 产. } \\
\frac{1}{2}\end{array}$ & 泗 & 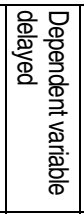 & \\
\hline & & USA & 76-79 & 0.70 & & Ho and Saunders (1981) \\
\hline \multicolumn{5}{|c|}{ Teoríco } & & Wong (1997) \\
\hline Money-centered bank & \multirow{4}{*}{ 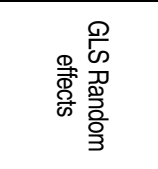 } & \multirow{4}{*}{ 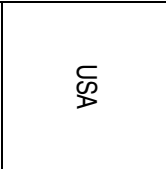 } & \multirow{4}{*}{ 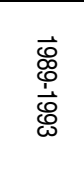 } & 0.56 & & \multirow{4}{*}{ Angbazo (1997) } \\
\hline Super-regional banks & & & & 0.29 & & \\
\hline Regional banks) & & & & 0.85 & & \\
\hline \multirow[t]{2}{*}{ Local banks } & & & & 0.43 & & \\
\hline & WLS Pooled & World & $88-95$ & 0.50 & & Demirgüç-Kunt et al. (1999) \\
\hline Germany & \multirow{6}{*}{ 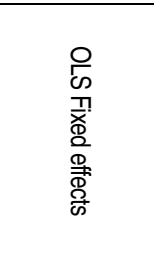 } & \multirow{6}{*}{ 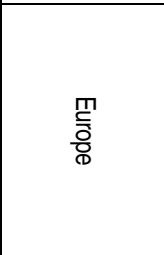 } & \multirow{6}{*}{ 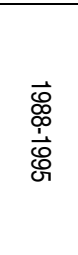 } & 0.65 & & \multirow{6}{*}{$\begin{array}{l}\text { Saunders and Schumacher } \\
(2000)\end{array}$} \\
\hline Italy & & & & 0.60 & & \\
\hline UK & & & & 0.60 & & \\
\hline Spain & & & & 0.30 & & \\
\hline Switzerland & & & & 0.40 & & \\
\hline US & & & & 0.35 & & \\
\hline France & \multirow{5}{*}{ 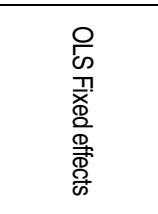 } & \multirow{5}{*}{$\begin{array}{l}\text { m } \\
\stackrel{5}{0} \\
\frac{0}{8}\end{array}$} & \multirow{5}{*}{ 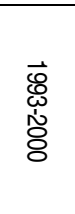 } & 0.98 & & \multirow{5}{*}{ Maudos and Fernández (2004) } \\
\hline Germany & & & & 0.98 & & \\
\hline Italy & & & & 0.97 & & \\
\hline Spain & & & & 0.98 & & \\
\hline All & & & & 0.96 & & \\
\hline all & \multirow{3}{*}{ 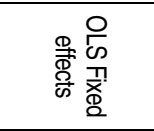 } & \multirow{3}{*}{ 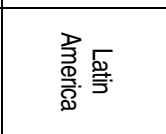 } & \multirow{3}{*}{$\begin{array}{l}0 \\
+ \\
0 \\
0\end{array}$} & 0.52 & & \multirow{3}{*}{ Martínez Peria and Mody (2004) } \\
\hline national & & & & 0.53 & & \\
\hline foreign & & & & 0.48 & & \\
\hline & OLS F. effects & Australia & $89-01$ & 0.91 & & Williams (2007) \\
\hline & GMM & Europe & $94-01$ & & $I$ & Carbo et al. (2007) \\
\hline & OLS F. effects & Europe & $96-02$ & 0.94 & & Lepetit et al. (2008) \\
\hline European Union & & & & 0.38 & & \\
\hline Enlargement 10 European Union & 策禹 & 응 & 点 & 0.33 & & Claeys and Vennet (2008) \\
\hline 5 Eastern Europe & & & & 0.35 & & \\
\hline & OLS F. effects & Eastern Europe & $00-05$ & 0.61 & & Schwaiger et al. (2008) \\
\hline & OLS F. effects & China & $96-03$ & 0.60 & & Zhou and Wong (2008) \\
\hline & GLS F. effects. & OCDE & $95-06$ & 0.99 & & Hawtrey and Liang (2008) \\
\hline Dynamic model & GMM & & & & + & \\
\hline Static model & OLS F. effects & Mexico & $93-05$ & 0.88 & & Maudos and Solls (2009) \\
\hline & OLS F. effects & Czech Republic & $00-06$ & & $I$ & Horváth (2009) \\
\hline & OLS F. effects & Eastern Europe & $95-06$ & 0.4 & & Poghosyan (2010) \\
\hline $1995-2000$ & $\Omega$ & & & 0.71 & & \\
\hline $2001-2006$ & $\frac{1}{\pi}$ & $\stackrel{\mathrm{m}}{\subseteq}$ & ci & 0.72 & & Kasman, Tunc, Vardar and Okan \\
\hline New countries of the European Union & $\frac{9}{\mathbb{D}}$ & $\frac{8}{8}$ & க் & 0.71 & & (2010) \\
\hline Members European Union & $\frac{2}{6}$ & & & 0.73 & & \\
\hline State-controlled banks & & & & 0.39 & & \\
\hline Foreign-owned banks & $\frac{0}{\infty}$ & & $\vec{\varnothing}$ & 0.06 & & \\
\hline Private domestic banks & $\underset{0}{\pi}$ & 苂. & $\begin{array}{l}\overline{0} \\
\text { సे }\end{array}$ & 0.14 & & $\begin{array}{l}\text { Fungácova and Poghosyan } \\
\text { (2011) }\end{array}$ \\
\hline Without Moscow & 㒸 & & ᄋ్ & 0.23 & & \\
\hline Total & & & & 0.15 & & \\
\hline All & & & & 0.69 & & \\
\hline Non-diversified & $\frac{O}{\infty}$ & $\frac{D}{d}$ & ì & nd & & Lin, Chung, Hseh and Wu (2012) \\
\hline High diversification & & & & nd & & \\
\hline 1997-2002 A. total & & & & & & \\
\hline $2003-2004$ & ه & .0 & $\vec{\varnothing}$ & & & Naunn $(2010)$ \\
\hline 1997-2002 productive assets. & 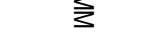 & 8 & సे & & & Nouyen (ZOIZ) \\
\hline $2003-2005$ & & m & & & & \\
\hline & & Pakistan & $01-10$ & & & Hussian (2013) \\
\hline & & & $\tilde{8}$ & 0.93 & & Expected sign \\
\hline Spanish entities & 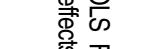 & 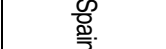 & 悥 & 0.93 & & Sign obtained on the regression \\
\hline & & & 온 & $\circ \stackrel{\circ}{\circ}$ & & Sign in interactions \\
\hline
\end{tabular}

